Article

\title{
Diffusive and Metabolic Constraints to Photosynthesis in Quinoa during Drought and Salt Stress
}

\author{
Dilek Killi $^{1, *}$ and Matthew Haworth ${ }^{2}$ \\ 1 Department of Agrifood Production and Environmental Sciences (DiSPAA), University of Florence, \\ Piazzale delle Cascine 28, 50144 Florence, Italy \\ 2 The National Research Council of Italy, Tree and Timber Institute (CNR-IVALSA), Presso Area di Ricerca \\ CNR, Via Madonna del Piano 10, Sesto Fiorentino, 50019 Florence, Italy; haworth@ivalsa.cnr.it \\ * Correspondence: dilek.killi@gmail.com; Tel.: +39-055-328-8271
}

Received: 25 September 2017; Accepted: 13 October 2017; Published: 17 October 2017

\begin{abstract}
Quinoa (Chenopodium quinoa Willd.) has been proposed as a hardy alternative to traditional grain crops in areas with warm-to-hot climates that are likely to experience increased drought and salt stress in the future. We characterised the diffusive and metabolic limitations to photosynthesis in quinoa exposed to drought and salt stress in isolation and combination. Drought-induced pronounced stomatal and mesophyll limitations to $\mathrm{CO}_{2}$ transport, but quinoa retained photosynthetic capacity and photosystem II (PSII) performance. Saline water $(300 \mathrm{mmol}$ $\mathrm{NaCl}$-equivalent to $60 \%$ of the salinity of sea-water) supplied in identical volumes to the irrigation received by the control and drought treatments induced similar reductions in stomatal and mesophyll conductance, but also reduced carboxylation of ribulose-1,5-bisphosphate carboxylase/oxygenase, regeneration of ribulose-1,5-bisphosphate, increased non-photochemical dissipation of energy as heat and impaired PSII electron transport. This suggests that ion toxicity reduced $P_{\mathrm{N}}$ via interference with photosynthetic enzymes and degradation of pigment-protein complexes within the thylakoid membranes. The results of this study demonstrate that the photosynthetic physiology of quinoa is resistant to the effects of drought, but quinoa may not be a suitable crop for areas subject to strong salt stress or irrigation with a concentration of saline water equivalent to a $300 \mathrm{mmol} \mathrm{NaCl}$ solution.
\end{abstract}

Keywords: Chenopodium quinoa; salinity; novel food crops; food security; stomatal conductance; mesophyll conductance; chlorophyll fluorescence

\section{Introduction}

Food security is jeopardized by climate change, population growth, unsustainable agriculture and the loss of agricultural land to urbanization/industrialization [1]. The development of crops with enhanced productivity and tolerance to abiotic stress may contribute toward sufficient future food production [2,3]. Quinoa (Chenopodium quinoa Willd.) has attracted attention as a novel food crop capable of producing comparatively large volumes of grain under adverse growth conditions $[4,5]$. Drought and salinity are two of the major causes of reduced plant growth and yield in areas with warm-to-arid climates [2,6], where quinoa has been proposed as an alternative to more traditional crops such as wheat (Triticum aestivum) [7]. Characterization of the diffusive and metabolic components of photosynthesis $\left(P_{\mathrm{N}}\right)$ in quinoa exposed to drought and salt stress may provide insights into the suitability of quinoa as a crop species for cultivation in areas subject to these stresses.

As soil dries and the availability of water for uptake by plants declines, hydraulic and chemical signals induce stomatal closure to reduce transpirative water-loss. Decreased stomatal conductance $\left(G_{S}\right)$ results in increased diffusive resistance to $\mathrm{CO}_{2}$-uptake, reducing the availability of $\mathrm{CO}_{2}$ within the 
chloroplast envelope where $P_{\mathrm{N}}$ occurs [8]. As $P_{\mathrm{N}}$ decreases, less energy is utilized for photochemistry and an increasing amount is dissipated as heat via xanthophylls (non-photochemical quenching) [9]. If drought stress is severe or occurs over a prolonged period, plants may not be able to dissipate excess energy safely and the protective mechanisms that neutralize reactive oxygen species may become degraded [2]. This may result in impaired performance of photosystem II (PSII) [10,11] and a reduction in photosynthetic capacity [12]. Plants may also respond to drought by reducing the expression of genes encoding photosynthetic enzymes, leading to decreased photosynthetic capacity [13]. Field trials of quinoa in the Mediterranean found that the yield of plants grown under rain-fed conditions were $42.6 \%$ lower than those receiving irrigation equivalent to potential evapotranspiration [7]. The retention of yield under drought in quinoa may be related to increased concentrations of the drought stress hormone abscisic acid within the xylem [14] inducing stomatal closure and increasing water use efficiency (WUE) [15-18]. The maintenance of $P_{\mathrm{N}}$ in quinoa during drought stress may be associated with enhanced antioxidant activities minimizing oxidative stress [19].

Salt stress lowers soil water potential, resulting in reduced water availability for plant growth [20]. This induces stomatal closure and limits $\mathrm{CO}_{2}$-uptake in a manner similar to the effects of drought stress [2]. Salinity may also induce ion toxicity where $\mathrm{Na}^{+}$inhibits metabolic function, in particular, enzymes involved in photosynthesis [21]. Irrigation of quinoa with increasingly saline water in Turkey (to an electrical conductivity of $40 \mathrm{dS} \mathrm{m}^{-1}$ ) did not significantly depress grain yield per plant [7]. Exposure to salt stress does result in a reduction in $P_{\mathrm{N}}$ and $G_{\mathrm{S}}$ in quinoa [22]. However, the deleterious effects of salt stress are less apparent in quinoa than in less salt-tolerant grain crops such as wheat (e.g., [23]) or rice (Oryza sativa) (e.g., [24]). The apparent tolerance of quinoa to salt stress may be related to its capacity to exclude $\mathrm{Na}^{+}$, increase the concentration of osmolytes such as $\mathrm{K}^{+}$within leaves and reduce the number of stomata over the leaf surface to reduce maximum $G_{S}$ [25-27].

Under field conditions, plants often experience drought and salt stress at the same time resulting in severely impaired growth [2]. However, the impact of these stresses in combination may not be additive in quinoa [28]. An in-depth analysis of the diffusive and biochemical components of the photosynthetic response to salinity and drought in combination and isolation would contribute to our understanding of the reported tolerance to abiotic stress in quinoa $[7,28,29]$. Moreover, the identification of attributes conducive to drought and salt tolerance may assist in the development of improved hardiness in new varieties of quinoa and/or staple crops that are more vulnerable to abiotic stress such as rice (e.g., [30]). We hypothesize that quinoa will maintain photosynthetic capacity and PSII performance under drought and salt stress, and that the limitations to $P_{\mathrm{N}}$ will be largely diffusive. This study aims to: (i) characterize the diffusive and biochemical constraints to $P_{\mathrm{N}}$ in quinoa subject to drought and/or salt stress; (ii) assess the performance of PSII electron transport and heat dissipation during drought and salt stress, and; (iii) discuss the photosynthetic response of quinoa to stress conditions likely to occur during growth in Mediterranean areas, and the potential to develop enhanced yield and tolerance of abiotic stress in quinoa through modification of photosynthetic and stomatal physiology.

\section{Results}

Drought and salt stress resulted in significant respective 17.0 and $19.3 \%$ reductions in leaf relative water content (RWC). A combination of drought and salinity induced a greater 36.9\% decrease in foliar RWC (Figure 1a). The leaf mass per area (LMA) of quinoa leaves was not significantly affected by the drought and salinity treatments with respect to control values; however, the LMA of leaves exposed to drought and salinity was significantly higher than those subjected to salinity only (Figure 1b). Drought and salinity in isolation induced respective reductions of $77.3 \%$ and $82.4 \%$ in leaf level $P_{\mathrm{N}}$. A combination of drought and salinity resulted in the lowest rates of $P_{\mathrm{N}}(96.5 \%$ lower than control values) (Figure 2a). These reductions in $P_{\mathrm{N}}$ with salinity and drought were associated with corresponding reductions in stomatal (Figure $2 \mathrm{~b}$ ) and mesophyll (Figure 2c) conductance. However, the reduction in $G_{\mathrm{S}}$ and mesophyll conductance $\left(G_{\mathrm{m}}\right)$ values between the individual drought and salinity treatments to the combined salinity and drought treatment did not correspond to a lower concentration of $\left[\mathrm{CO}_{2}\right]$ 
within the chloroplast envelope $\left(C_{c}\right)$ (Figure $2 \mathrm{~d}$ ); indeed, $C_{c}$ was identical in all the salinity and/or drought treatments, approximately $45 \%$ lower than the levels of $C_{c}$ in the control plants. This may be associated with the similarity in PSII electron transport rate $\left(J_{\mathrm{F}}\right)$ values observed in the drought and salinity treatments (Figure 2e) used in the variable J calculation. Rates of $P_{\mathrm{N}}$ were positively correlated to stomatal, mesophyll and total conductance to $\mathrm{CO}_{2}$, with the significance of the relationship greatest between $P_{\mathrm{N}}$ and total conductance to $\mathrm{CO}_{2}\left(G_{\mathrm{tot}}\right)$ (Figure 3). Rates of photorespiration $\left(P_{\mathrm{PR}}\right)$ declined respectively by $42.1 \%$ and $55.0 \%$ in the individual drought and salinity treatments, and were $87.9 \%$ lower in the combined drought and salinity treatment (Figure $2 \mathrm{f}$ ). However, as a proportion of $P_{\mathrm{N}}, P_{\mathrm{PR}}$ was significantly greater in the plants exposed to drought and/or salt stress than the control (Figure 2g).

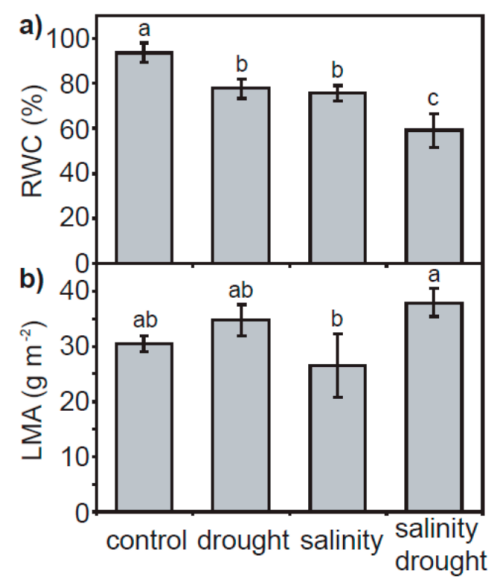

Figure 1. Relative water content (a) and leaf mass per area (b) of quinoa leaves from plants subject to the control, drought, salinity and salinity-drought treatments. Error bars indicate one standard deviation either side of the mean. Letters indicate significant difference using a one-way ANOVA and a least significant difference (LSD) post-hoc test.
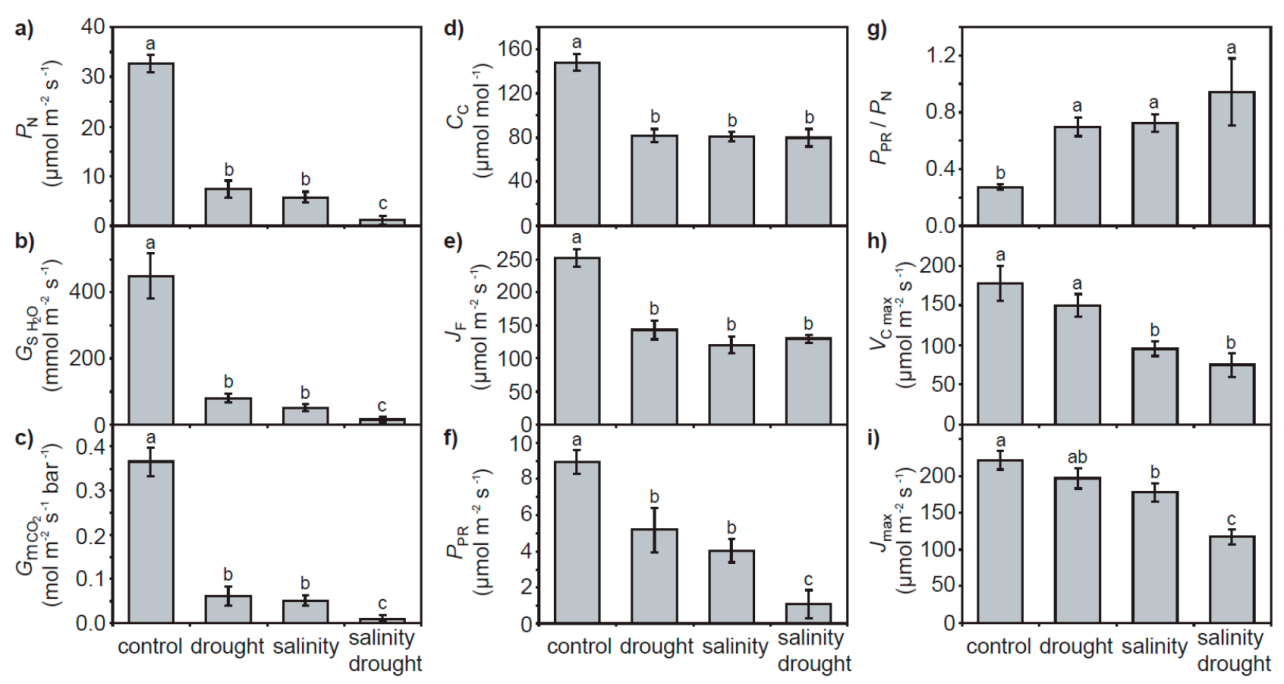

Figure 2. Photosynthetic parameters of quinoa subject to the control, drought, salinity and salinity-drought treatments: (a) photosynthesis; (b) stomatal conductance to water vapor; (c) mesophyll conductance to $\mathrm{CO}_{2} ;(\mathbf{d})$ concentration of $\left[\mathrm{CO}_{2}\right]$ within the chloroplast envelope; (e) electron transport; (f) photorespiration; (g) ratio of photorespiration to photosynthesis; (h) the maximum carboxylation rate of RubisCO, and; (i) the maximum rate of electron transport for regeneration of RuBP. Error bars indicate one standard deviation either side of the mean. Letters indicate significant difference using a one-way ANOVA and an LSD post hoc test. 


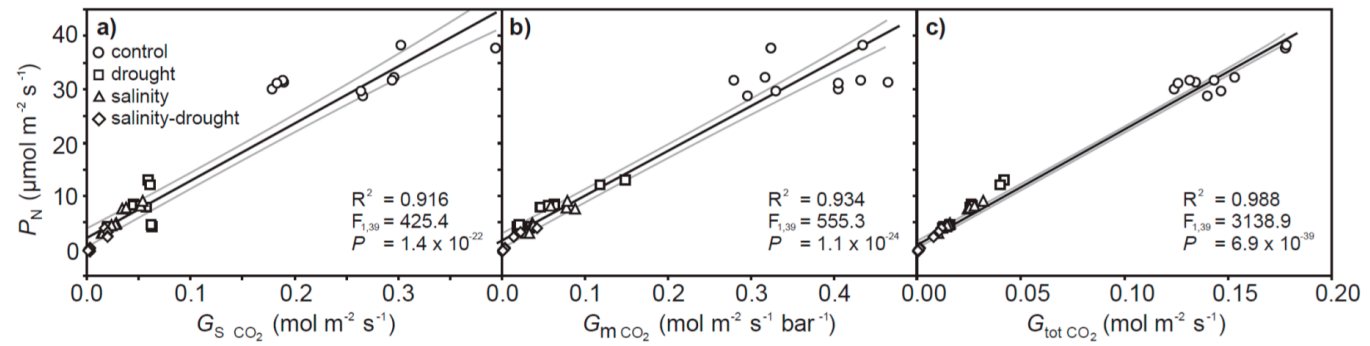

Figure 3. The relationship between photosynthesis with stomatal (a), mesophyll (b) and total (c) conductance to $\mathrm{CO}_{2}$. The black line indicates the line of best fit and the two grey lines either side indicate the $95 \%$ confidence intervals of the mean. Linear regression was used to assess the significance of any relationship.

The photosynthetic capacity of the quinoa plants was not significantly affected by the drought treatment (Figure 2h,j and Figure 4a). Salinity resulted in a lower maximum carboxylation rate of ribulose-1,5-bisphosphate carboxylase/oxygenase (RubisCO) $\left(V \mathrm{c}_{\max }\right)$ and lower maximum rate of electron transport for regeneration of ribulose-1,5-bisphosphate $(\mathrm{RuBP})\left(J_{\max }\right)$, and a combination of drought and salinity further reduced $J_{\max }$ (Figure $2 \mathrm{~h}, \mathrm{i}$ ). The $J_{\max } / V \mathrm{c}_{\max }$ ratio was not significantly altered in any of the drought and/or salinity treatments with respect to the control plants (one-way ANOVA with LSD post hoc: $\mathrm{F}_{3,17}=1.453 ; p=0.270$ ). Mesophyll conductance values calculated from the $P_{\mathrm{N}}-C_{\mathrm{i}}$ response curves [31] were broadly consistent with those determined by the variable J approach [32] (Figure 4b).
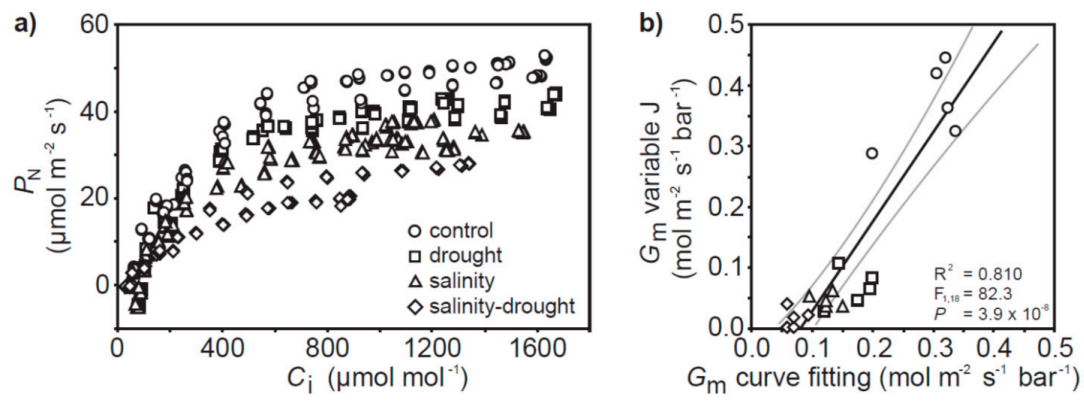

Figure 4. (a) $P_{\mathrm{N}}-C_{\mathrm{i}}$ response curves of quinoa subject to the control, drought, salinity and salinity-drought treatments; (b) comparison of $G_{\mathrm{m}}$ values calculated using the variable J [32] and $P_{\mathrm{N}}-C_{\mathrm{i}}$ curve fitting [31] methods. The black line indicates the line of best fit and the two grey lines either side indicate the $95 \%$ confidence intervals of the mean. Linear regression was used to assess the significance of any relationship.

Dark-adapted chlorophyll fluorescence parameters measured by pulse amplitude modulated fluorimetry indicated that the maximum $\left(F_{\mathrm{v}} / F_{\mathrm{m}}\right.$ : Figure $\left.5 \mathrm{a}\right)$ and actual ( $\Phi P S I I$ : Figure $\left.5 \mathrm{~b}\right)$ quantum efficiencies of PSII and non-photochemical quenching of chlorophyll a fluorescence (qNP and NPQ: Figure $5 c, d$ ) were significantly lower in the salinity and salinity-drought treatments, while plants grown under the drought treatment exhibited no significant effect on PSII. Likewise, steps of chlorophyll fluorescence induction transient O-J-I-P (OJIP) curve analysis of the transient response of chlorophyll a fluorescence showed no significant effect of the drought treatment on PSII in quinoa (Figure 6 and Table 1). Salt stress in the salinity and salinity-drought treatments resulted in significant effects on the OJIP curves of the quinoa leaves: minimum fluorescence yield in dark-adapted conditions $\left(F_{\mathrm{o}}\right)$, quantum yield of energy dissipation $\left(\phi \mathrm{D}_{\mathrm{o}}\right)$, absorption of chlorophyll antennae per reaction centre $(\mathrm{ABS} / \mathrm{RC})$ and the flux of energy dissipated for each reaction centre $\left(\mathrm{DI}_{\mathrm{o}} / \mathrm{RC}\right)$ were all significantly increased, while maximum fluorescence yield in dark-adapted conditions $\left(F_{\mathrm{m}}\right)$, the efficiency of the 
electron chain flux in the I to P phase of the chlorophyll a fluorescence $\left(\Delta V_{I P}\right)$, efficiency of electron carriers in reducing end electron acceptors at the PSI acceptor $\left(\delta R_{\mathrm{o}}\right)$, maximum quantum yield of PSII photochemistry $\left(F_{\mathrm{v}} / F_{\mathrm{m}}\right)$, initial quantum yield of electron transport $\left(\phi \mathrm{E}_{\mathrm{o}}\right)$, the electron flux beyond plastoquinone A per reaction centre $\left(\mathrm{ET}_{\mathrm{o}} / \mathrm{RC}\right)$, a performance index based on the photochemical and non-photochemical energy absorption of chlorophyll antennae $\left(\mathrm{PI}_{\mathrm{ABS}}\right)$ and a performance index incorporating the concentration of reaction centres $\left(\mathrm{PI}_{\mathrm{TOT}}\right.$ ) were all reduced (Figure $6 \mathrm{~b}$ and Table 1 ).

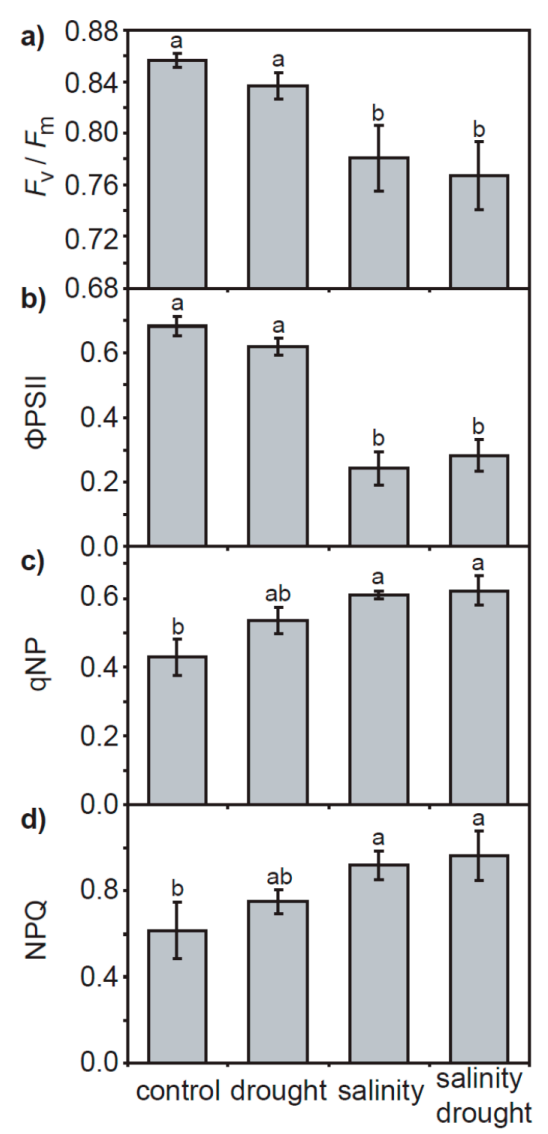

Figure 5. Pulse amplitude modulation chlorophyll fluorescence analysis of quinoa plants grown in the control, drought, salinity and salinity-drought treatments: (a) $F_{\mathrm{v}} / F_{\mathrm{m}}$; (b) ФPSII; (c) qNP, and; (d) NPQ. Error bars indicate one standard deviation either side of the mean. Letters indicate significant difference using a Kruskal-Wallis non-parametric test.
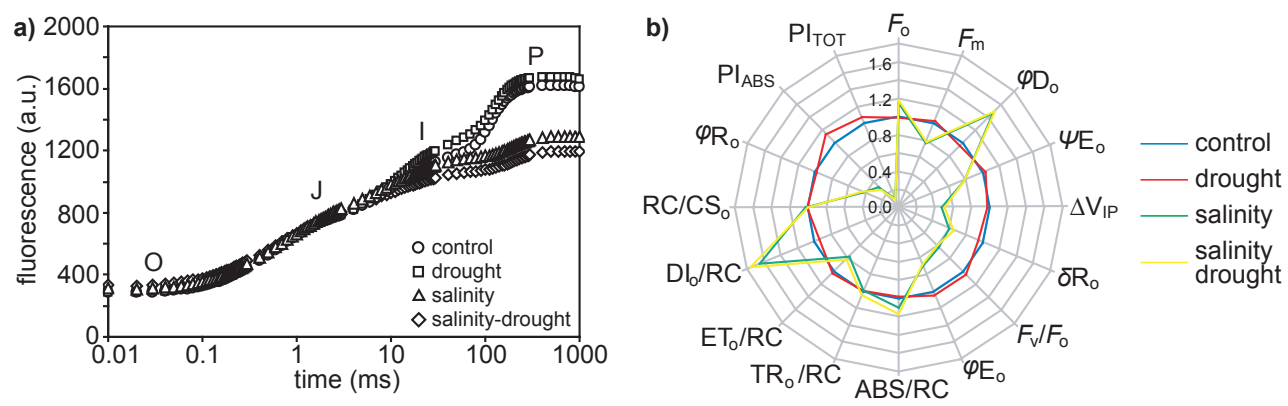

Figure 6. Analysis of the chlorophyll fluorescence transient of quinoa plants grown in the control, drought, salinity and salinity-drought treatments: (a) average OJIP induction curves; (b) spider plot of parameters (see supplementary information Table S1 for definitions and descriptions) extrapolated from the OJIP transient expressed in relation to control values. 
Table 1. Analysis of parameters calculated from the chlorophyll fluorescence OJIP transient (Figure 6a) of quinoa plants under control, drought, salinity and a combination of salinity and drought treatments. Values are the means of five replicates (three measurements per replicate). \pm indicates standard error. Values followed by different letters are significantly different at the $p<0.05$ level using a Kruskal-Wallis nonparametric test.

\begin{tabular}{|c|c|c|c|c|}
\hline Treatment & $F_{\mathrm{o}}$ & $F_{\mathrm{m}}$ & $\phi \mathrm{D}_{\mathrm{o}}$ & $\Psi \mathrm{E}_{\mathrm{o}}$ \\
\hline control & $260 \pm 10.0^{b}$ & $1621 \pm 19.3^{a}$ & $0.180 \pm 0.007^{b}$ & $0.665 \pm 0.014^{a}$ \\
\hline drought & $257 \pm 4.2^{b}$ & $1666 \pm 12.8^{a}$ & $0.172 \pm 0.003^{b}$ & $0.686 \pm 0.007^{\mathrm{a}}$ \\
\hline salinity & $297 \pm 9.8^{a}$ & $1252 \pm 26.7^{b}$ & $0.263 \pm 0.012^{\mathrm{a}}$ & $0.516 \pm 0.011^{b}$ \\
\hline salinity-drought & $306 \pm 5.1^{\mathrm{a}}$ & $1270 \pm 33.6^{b}$ & $0.268 \pm 0.007^{\mathrm{a}}$ & $0.514 \pm 0.018^{b}$ \\
\hline Treatment & $\Delta \mathrm{V}_{\text {IP }}$ & $\delta \mathbf{R}_{\mathbf{o}}$ & $F_{\mathrm{v}} / F_{\mathrm{o}}$ & $\phi \mathrm{E}_{\mathrm{o}}$ \\
\hline control & $0.390 \pm 0.014^{\mathrm{a}}$ & $0.587 \pm 0.015^{\mathrm{a}}$ & $4.64 \pm 0.18^{a}$ & $0.546 \pm 0.015^{\mathrm{a}}$ \\
\hline drought & $0.380 \pm 0.010^{\mathrm{a}}$ & $0.554 \pm 0.013^{\mathrm{a}}$ & $4.84 \pm 0.10^{\mathrm{a}}$ & $0.568 \pm 0.007^{\mathrm{a}}$ \\
\hline salinity & $0.184 \pm 0.010^{b}$ & $0.356 \pm 0.016^{b}$ & $2.89 \pm 0.17^{b}$ & $0.381 \pm 0.012^{b}$ \\
\hline salinity-drought & $0.197 \pm 0.010^{b}$ & $0.383 \pm 0.015^{b}$ & $2.75 \pm 0.11^{b}$ & $0.376 \pm 0.015^{b}$ \\
\hline Treatment & $\mathrm{ABS} / \mathrm{RC}$ & $\mathrm{TR}_{\mathrm{o}} / \mathrm{RC}$ & $\mathrm{ET}_{\mathrm{o}} / \mathrm{RC}$ & $\mathrm{DI}_{\mathrm{o}} / \mathrm{RC}$ \\
\hline control & $1.574 \pm 0.024^{b}$ & $1.291 \pm 0.021^{\mathrm{ab}}$ & $0.857 \pm 0.020^{a}$ & $0.283 \pm 0.013^{b}$ \\
\hline drought & $1.545 \pm 0.015^{b}$ & $1.280 \pm 0.010^{a b}$ & $0.877 \pm 0.010^{\mathrm{a}}$ & $0.266 \pm 0.006^{b}$ \\
\hline salinity & $1.736 \pm 0.069^{\mathrm{ab}}$ & $1.270 \pm 0.030^{\mathrm{b}}$ & $0.655 \pm 0.020^{b}$ & $0.466 \pm 0.041^{\mathrm{a}}$ \\
\hline salinity-drought & $1.846 \pm 0.051^{\mathrm{a}}$ & $1.348 \pm 0.030^{\mathrm{a}}$ & $0.693 \pm 0.028^{b}$ & $0.498 \pm 0.024^{\mathrm{a}}$ \\
\hline Treatment & $\mathrm{RC} / \mathrm{CS}_{\mathrm{o}}$ & $\phi \mathbf{R}_{\mathrm{o}}$ & $\mathbf{P I}_{\mathrm{ABS}}$ & $\mathbf{P I}_{\text {TOT }}$ \\
\hline control & $184.6 \pm 6.2^{b}$ & $0.320 \pm 0.013^{a}$ & $61.5 \pm 6.1^{\mathrm{a}}$ & $30.6 \pm 4.2^{\mathrm{a}}$ \\
\hline drought & $185.1 \pm 2.7^{\mathrm{ab}}$ & $0.314 \pm 0.009^{\mathrm{a}}$ & $69.6 \pm 3.6^{a}$ & $32.7 \pm 2.7^{a}$ \\
\hline salinity & $188.8 \pm 2.8^{a}$ & $0.135 \pm 0.007^{b}$ & $19.0 \pm 2.1^{b}$ & $3.1 \pm 0.5^{b}$ \\
\hline salinity-drought & $184.6 \pm 4.0^{\mathrm{ab}}$ & $0.143 \pm 0.008^{b}$ & $16.4 \pm 1.8^{b}$ & $2.8 \pm 0.4^{b}$ \\
\hline
\end{tabular}

\section{Discussion}

The effects of physical and osmotic water deficit associated with drought and salinity on plant gas exchange and photosynthetic physiology can be broadly similar, particularly in the early stages of stress (e.g., [33,34]). In the present study, quinoa exhibited largely distinct photosynthetic and gas exchange responses to drought and salt stress. The effects of drought on $P_{\mathrm{N}}$ in quinoa were largely diffusive, characterized by reduced stomatal (e.g., [35]) and mesophyll (e.g., [8,36]) conductance to $\mathrm{CO}_{2}$. The rapid stomatal closure of quinoa is characteristic of 'isohydric' behavior [37] to maintain leaf water potential and RWC [38]. As drought induced significant reductions in the foliar RWC of quinoa (Figure 1a), this would suggest that the stress was pronounced. Nevertheless, removal of stomatal limitations via the use of prolonged exposure to sub-ambient $\left[\mathrm{CO}_{2}\right]$ [39] indicated that quinoa had retained photosynthetic capacity (Figure $4 \mathrm{a}$ ). Likewise, chlorophyll fluorescence analysis suggested that drought stress had little significant impact upon PSII photochemistry or non-photochemical quenching (Figures 5 and 6). This is consistent with previous observations of enhanced antioxidant activity in quinoa [19] stabilizing the thylakoid membranes within the chloroplast envelope where PSII occurs [40]. Constraints to the uptake of $\mathrm{CO}_{2}$ via reduced $\mathrm{G}_{\mathrm{m}}$ in the drought and salinity treatments was a significant factor in the $P_{\mathrm{N}}$ of quinoa (Figure 3b). Mesophyll conductance to $\mathrm{CO}_{2}$ is determined by physical [41,42] and biochemical [43] factors. The lack of any significant difference in LMA between the leaves of quinoa from the control and salinity and/or drought treatments would indicate that the reduced $G_{m}$ observed in this study is largely the result of reduced biochemical uptake of $\mathrm{CO}_{2}$ across the mesophyll layer (e.g., [36]).

Exposure to salt stress in isolation led to reductions in transport of $\mathrm{CO}_{2}$ similar to those observed in drought-stressed quinoa (Figure 2c). Moreover, salinity also induced reductions in $V_{c_{\max }}$ and $J_{\max }$ indicative of a loss of photosynthetic capacity (Figure $2 \mathrm{~h}, \mathrm{i}$ and Figure $4 \mathrm{a}$ ). The reductions in $V_{\mathrm{c}_{\max }}$ found in salt-stressed quinoa would be consistent with impaired carboxylation of RubisCO [44,45] 
and/or reduced RubisCO content [46]. Salt stress also reduced the capacity for RuBP regeneration in quinoa indicative of reduced RuBP availability [45] and expression [47,48], particularly in the salinity drought treatment. The quinoa exposed to the salinity-drought treatment exhibited the lowest $G_{\mathrm{S}}$ of all the treatments (Figure $2 \mathrm{~b}$ ), suggesting that $\mathrm{Na}^{+}$had not interfered with $\mathrm{K}^{+}$stomatal signaling and guard cell osmoregulation (cf. [49]) consistent with exclusion of $\mathrm{Na}^{+}$from salt-stressed quinoa [25].

Excessive concentrations of both $\mathrm{Na}^{+}$and $\mathrm{Cl}^{-}$interfere with plant physiology; however, $\mathrm{Cl}^{-}$ is generally more damaging to the function of photosynthetic enzymes and plant growth $[50,51]$. The impact of excess $\mathrm{Cl}^{-}$is particularly evident in the performance of PSII [41], possibly due to disruption of the role of $\mathrm{Cl}^{-}$in the oxygen-evolving complex of PSII [52,53]. Analysis of the chlorophyll fluorescence transient in quinoa exposed to the salinity and salinity-drought treatments would be consistent with ion toxicity effects on PSII function (Figures 5 and 6). The reduction in $F_{\mathrm{V}} / F_{\mathrm{O}}$ (an indicator of the activity of the oxygen-evolving complex) values is consistent with reduced efficiency in the oxygen-evolving complex on the electron donor side of PSII [54]. The reduced maximum quantum efficiency of PSII (Figure 5a), enhanced dissipation of intercepted energy as heat (Figure $5 c, d$ ) and increased pool of reduced plastoquinone (the area above the OJIP curve) (Figure 6a) indicate reduced potential for photochemistry in the quinoa plants exposed to salinity [55]. The reduction in $F_{\mathrm{m}}$ values observed in the quinoa plants subject to salt stress may be suggestive of reduced numbers of light harvesting complex antennae [56] as the chlorophyll content declined due to $\mathrm{Cl}^{-}$toxicity [57]. The reduction of the $\mathrm{J}$, I and P levels of the fluorescence transient also indicates impaired electron transport [55] alongside the degradation of chlorophyll within the thylakoid complexes of salt-stressed quinoa (Figure 6a). The decrease in values of $\Psi \mathrm{E}_{\mathrm{O}}, \Delta \mathrm{V}_{\mathrm{IP}}, \phi \mathrm{R}_{\mathrm{o}}$ and $\delta \mathrm{R}_{\mathrm{o}}$ are consistent with reduced electron transfer from plastoquinone A to B and impaired PSI electron acceptors [58,59]. Salinity also reduced the number of open reaction centres in PSII (higher $F_{\mathrm{o}}$ indicating an increase in the number of inactive reaction centres incapable of electron transfer from reduced plastoquinone $\mathrm{A}$ ), compounding the lower electron flux (i.e., reduced $\mathrm{ET}_{\mathrm{o}} / \mathrm{RC}$ ). This resulted in greater absorption (i.e., higher $\mathrm{ABS} / \mathrm{RC}$ ) and dissipation (i.e., higher $\mathrm{DI}_{\mathrm{o}} / \mathrm{RC}$ ) of energy per reaction centre (and reduced quantum yield of energy dissipation, $\phi \mathrm{D}_{\mathrm{o}}$ ), contributing to the lower overall performance indicators of PSII in the conservation and transport efficiency of excited electrons to PSI acceptors (i.e., lower PI ${ }_{\mathrm{ABS}}$ and $\mathrm{PI}_{\mathrm{TOT}}$ [55]. The disruption to the intersystem electron transport and end electron receptors in PSII is a major source of reactive oxygen species production [60], suggesting that the quinoa exposed to salinity experienced a higher level of oxidative stress than their control or drought treatment counterparts. The impact of salt stress on the performance of PSII in quinoa was mostly identical in the salinity and salinity-drought treatments (Figures 5 and 6; Table 1), possibly suggesting that these effects were largely due to ion toxicity and not reduced water availability.

\section{Materials and Methods}

\subsection{Plant Material and Growth Conditions}

Seeds of quinoa (Chenopodium quinoa Willd. var red head) were germinated in moist sand. Two weeks after germination, the plants were transplanted into 201 pots filled with a $90 \%$ sand to $10 \%$ $\mathrm{w} / \mathrm{w}$ commercial compost mixture (COMPO Terriccio Universale, COMPO Italia, Cesano Maderno, Italy) which has $22 \%$ of field capacity (FC) water content. The plants were grown outside from June to July 2016 in full sunlight in Sesto Fiorentino, Central Italy, and watered daily to pot capacity and supplied with a complete commercial nutrient solution twice a week to provide nutrients at free access rates (COMPO Concime Universale, NPK 7-5-7, B, Cu, Fe, Mn, Mo, Zn). After a further four weeks, when the plants were approximately $1 \mathrm{~m}$ high, the experimental treatments were instigated. The field capacity (FC) water content was determined gravimetrically [61]. The pots were weighed each day and the amount of water lost replaced for the control ( $80 \%$ of FC) and drought (30\% of FC) water target. The treatments were: control (irrigation to $80 \% \mathrm{FC}$ ), drought ( $30 \%$ of FC), salinity ( $80 \% \mathrm{FC}$ using $300 \mathrm{mmol}$ saline water) and salinity-drought ( $30 \% \mathrm{FC}$ using $300 \mathrm{mmol}$ saline water). The saline water 
was prepared from a solution of deionized water and $\mathrm{NaCl}$ ( $\geq 99.5 \%$ purity; Sigma Aldrich, St. Louis, MO, USA) to a concentration of $300 \mathrm{mmol}$ (i.e., $60 \%$ of the salinity of sea water). A concentration of $300 \mathrm{mmol}$ was chosen as [62] observed that this was the concentration at which the effects of salinity became apparent in the seed germination and above-below ground growth parameters of quinoa. The drought and salinity-drought treatments were achieved by allowing the soil to dry to the target pot weight (this took two days) and then replenishing the water or saline solution each day to maintain the target weight. Five replicate plants were subject to each treatment.

\subsection{Leaf Gas Exchange Analysis}

Point measurements of leaf gas exchange and chlorophyll fluorescence were repeated on the uppermost fully expanded leaf of each replicate plant over the final two days of the two-week experimental period between 09:00 and 11:00 using a LiCor Li6400XT fitted with a 6400-40 $2 \mathrm{~cm}^{2}$ leaf cuvette (Li-Cor, Inc., Lincoln NE, USA). Conditions in the leaf cuvette were set to a photosynthetic photon flux density (PPFD) of $2000 \mu \mathrm{mol} \mathrm{m}{ }^{-2} \mathrm{~s}^{-1}$, leaf temperature of $25{ }^{\circ} \mathrm{C},\left[\mathrm{CO}_{2}\right]$ of $400 \mu \mathrm{mol} \mathrm{mol}^{-1}$ and relative humidity of $60 \%$. The multi-phase fluorescence setting was used with an initial saturating pulse of $8000 \mu \mathrm{mol} \mathrm{m}{ }^{-2} \mathrm{~s}^{-1}$ [63]. Mesophyll conductance $\left(G_{\mathrm{m}}\right)$ was determined using the variable J method described in [32]:

$$
G_{\mathrm{m}}=\frac{P_{\mathrm{N}}}{C_{\mathrm{i}}-\frac{\Gamma *\left[J_{\mathrm{F}}+8 \times\left(P_{\mathrm{N}}+\mathrm{R}_{\mathrm{d}}\right)\right]}{J_{\mathrm{F}}-4 \times\left(P_{\mathrm{N}}+\mathrm{R}_{\mathrm{d}}\right)}}
$$

The $\mathrm{CO}_{2}$ compensation point to photorespiration $\left(\Gamma^{*}\right)$ was calculated using the RubisCO specificity factor described in [64]. The Kok method [65] was used to estimate respiration in the light $\left(R_{\mathrm{d}}\right)$ (PPFD levels of 400, 300, 200, 100, 80, 60, 30, $\left.0 \mu \mathrm{mol} \mathrm{m} \mathrm{m}^{-2} \mathrm{~s}^{-1}\right)$. The effect of variation in the sub-stomatal concentration of $\left[\mathrm{CO}_{2}\right]\left(\mathrm{C}_{\mathrm{i}}\right)$ on $R_{\mathrm{d}}$ was corrected using the iterative method outlined in [66]. The PSII electron transport rate $\left(J_{\mathrm{F}}\right)$ was calculated from chlorophyll fluorescence as:

$$
J_{\mathrm{F}}=\mathrm{PPFD} \times \Phi \text { PSII } \times \alpha \times \beta
$$

where the partitioning factor between photosystems I and II is considered to be 0.5 ( $\beta$ ); leaf absorbance $(\alpha)$ is assumed to be 0.85 [67]; and, the actual quantum efficiency of PSII (ФPSII) determined as:

$$
\text { DPSII }=\frac{F_{\mathrm{m}}{ }^{\prime}-F_{\mathrm{s}}}{F_{\mathrm{m}}{ }^{\prime}}
$$

where $F_{\mathrm{m}}{ }^{\prime}$ is the maximal fluorescence and $F_{\mathrm{s}}$ is the steady-state fluorescence under light-adapted conditions [11]. The concentration of $\left[\mathrm{CO}_{2}\right]$ within the chloroplast envelope was calculated using the value of $G_{\mathrm{m}}$ derived from the variable J method as:

$$
C_{\mathrm{c}}=C_{\mathrm{i}}-\frac{P_{\mathrm{N}}}{G_{\mathrm{m}}}
$$

where $C_{i}$ is the concentration of $\left[\mathrm{CO}_{2}\right]$ within the internal sub-stomatal air-space [68]. Photorespiration $\left(P_{\mathrm{PR}}\right)$ was determined following Sharkey [69]:

$$
P_{\mathrm{PR}}=\frac{P_{\mathrm{N}}+R_{\mathrm{d}}}{\frac{C_{\mathrm{c}}}{\Gamma *}-1}
$$

Total conductance to $\mathrm{CO}_{2}$ was calculated as:

$$
G_{\mathrm{tot}}=\frac{G_{\mathrm{s}} \times G_{\mathrm{m}}}{G_{\mathrm{s}}+G_{\mathrm{m}}}
$$

The response of $P_{\mathrm{N}}$ to increasing $C_{\mathrm{i}}$ was determined in the last four days of the experimental treatment using a LiCor Li6400-40 attached to a $6 \mathrm{~cm}^{2}$ LiCor 6400-02B leaf cuvette with red and blue 
LEDs. The uppermost fully expanded leaf on five replicate plants for each treatment was analyzed. The $P_{\mathrm{N}}-C_{\mathrm{i}}$ response of quinoa is sensitive to light intensity [70]; therefore, a saturating PPFD of $2000 \mu \mathrm{mol} \mathrm{m} \mathrm{m}^{-2} \mathrm{~s}^{-1}$ was used. The concentration of $\left[\mathrm{CO}_{2}\right]$ within the leaf cuvette was lowered to $50 \mu \mathrm{mol} \mathrm{mol}{ }^{-1}$ for $60 \mathrm{~min}$ to fully open stomata and remove any diffusive limitations to $P_{\mathrm{N}}$ before $\left[\mathrm{CO}_{2}\right]$ was increased in stages every 3 to $4 \mathrm{~min}$ when $P_{\mathrm{N}}$ had stabilized $\left(\left[\mathrm{CO}_{2}\right]\right.$ steps: 50, 100, 200, 300, 400, 600, 800, 1000, 1200, 1400, 1600, 1800, $2000 \mu \mathrm{mol} \mathrm{mol}^{-1}$ ) [39]. Leaf temperature remained at $25{ }^{\circ} \mathrm{C}$ and relative humidity at $60 \%$ throughout the $P_{\mathrm{N}}-C_{\mathrm{i}}$ response curve. To correct for diffusion leaks during the $P_{\mathrm{N}}-C_{\mathrm{i}}$ curve, a dead leaf was placed within the leaf cuvette and the step changes in $\left[\mathrm{CO}_{2}\right]$ repeated following [71]. The maximum carboxylation rate of RubisCO $\left(V c_{\max }\right)$, the maximum rate of electron transport for regeneration of ribulose-1,5-bisphosphate $(\mathrm{RuBP})\left(J_{\max }\right)$ and mesophyll conductance $\left(G_{m}\right)$ were calculated from the $P_{\mathrm{N}}-C_{\mathrm{i}}$ curve [31]. The parameters $V \mathrm{c}_{\max }$ and $J_{\max }$ were calculated from the $P_{\mathrm{N}}-C_{\mathrm{i}}$ curve and not the $P_{\mathrm{N}}-C_{\mathrm{c}}$ curve as this would require the assumption that $G_{\mathrm{m}}$ is constant at all $\left[\mathrm{CO}_{2}\right]$ levels, while evidence suggests that $G_{\mathrm{m}}$ may vary with $\left[\mathrm{CO}_{2}\right][43]$.

\subsection{Chlorophyll Fluorescence}

Chlorophyll fluorescence analyses were performed over the last three days of the experimental treatments on the uppermost fully expanded leaf of each plant. Transient analysis of chlorophyll, a fluorescence was undertaken using a Hansatech Handy-PEA (plant efficiency analyzer) fluorimeter (Hansatech, King's Lynn, UK). Leaves were dark-adapted for $30 \mathrm{~min}$ and then exposed to a saturating light pulse (intensity $>3000 \mu \mathrm{mol} \mathrm{m} \mathrm{m}^{-2} \mathrm{~s}^{-1}$, excitation light of $650 \mathrm{~nm}$ ) [55]. This results in a polyphasic transient of chlorophyll fluorescence: O (20-50 $\mu \mathrm{s}), \mathrm{J}(2 \mathrm{~ms}), \mathrm{I}(30 \mathrm{~ms})$ and P (peak). A summary of the theoretical basis and analysis of OJIP curves is given in Strasser et al. [55] and Kalaji et al. [10]. The OJIP curves were analyzed using Biolyzer 4 HP v.3 (Bioenergetics Laboratory, University of Geneva, Geneva, Switzerland). The parameters extrapolated from the OJIP curve and analyzed in this study are: $F_{\mathrm{o}}$, minimum fluorescence yield in dark-adapted conditions; $F_{\mathrm{m}}$, maximum fluorescence yield in dark-adapted conditions; $\phi \mathrm{D}_{\mathrm{o}}$, quantum yield of energy dissipation $\left(F_{\mathrm{o}} / F_{\mathrm{m}}\right)$ at time $0 ; \Psi E_{\mathrm{O}}$, the probability that harvested excitation energy is utilized for electron transport to the primary plastoquinone A acceptor of PSII; $F_{\mathrm{V}} / F_{\mathrm{O}}$, an indicator of the activity of the oxygen-evolving complex on the donor side of PSII; $\Delta \mathrm{V}_{\mathrm{IP}}$, a relative measure of the I to P phase of the chlorophyll a fluorescence transient indicating the efficiency of the electron chain flux through photosystem I (PSI); $\delta \mathrm{R}_{\mathrm{o}}$, efficiency of electron carriers in reducing end electron acceptors at the PSI acceptor; $F_{\mathrm{V}} / F_{\mathrm{m}}$, maximum quantum yield of PSII photochemistry; $\phi \mathrm{E}_{\mathrm{O}}$ initial quantum yield of electron transport at time $0 ; \mathrm{ABS} / \mathrm{RC}$, absorption of chlorophyll antennae per reaction centre; $\mathrm{ET}_{\mathrm{o}} / \mathrm{RC}$, the electron flux beyond plastoquinone $A$ per reaction centre; $\mathrm{TR}_{\mathrm{o}} / \mathrm{RC}$, the flux of trapped energy per reaction centre leading to the reduction of plastoquinone $\mathrm{A} ; \mathrm{DI}_{\mathrm{O}} / \mathrm{RC}$, the flux of energy dissipated for each reaction centre; $R C / C S_{0}$, the density of PSII plastoquinone A reducing reaction centres; $\phi R_{0}$, quantum yield of the reduction of final stage acceptors at the PSI stage; $\mathrm{PI}_{\mathrm{ABS}}$, a performance index based on the photochemical and non-photochemical energy absorption of chlorophyll antennae; $\mathrm{PI}_{\mathrm{TOT}}$, a performance index incorporating the concentration of reaction centres, the quantum yield of PSII photochemistry, capacity for uptake of electrons between PSII and PSI and the efficiency of electron transfer from reduced intersystem electron acceptors to the final stage PSI electron [55]. More detailed definitions, descriptions and formulae for the PEA parameters used in this study are given in supplementary information Table $\mathrm{S} 1$.

The maximum $\left(F_{\mathrm{v}} / F_{\mathrm{m}}\right)$ and actual ( $\Phi$ PSII) quantum yields of photosystem II and the non-photochemical quenching co-efficient, qNP and NPQ, were recorded using a Hansatech Pulse-Amplitude-Modulation FMS-2 fluorimeter. After 30 min dark adaptation, the leaves were exposed to a saturating pulse of $10,000 \mu \mathrm{mol} \mathrm{m} \mathrm{m}^{-2} \mathrm{~s}^{-2}$, then actinic light of $1000 \mu \mathrm{mol} \mathrm{m}^{-2} \mathrm{~s}^{-1}$ 
for a minimum of $10 \mathrm{~min}$ followed by a second saturating pulse. To gauge energy dissipation via non-photochemical quenching, the co-efficient qNP and NPQ were used:

$$
\begin{aligned}
\mathrm{qNP} & =\frac{F_{\mathrm{m}}-F_{\mathrm{m}}{ }^{\prime}}{F_{\mathrm{m}}-F_{\mathrm{o}}}, \\
\mathrm{NPQ} & =\frac{F_{\mathrm{m}}-F_{\mathrm{m}}{ }^{\prime}}{F_{\mathrm{m}}{ }^{\prime}}
\end{aligned}
$$

\subsection{Relative Water Content and Leaf Mass per Area}

At the end of the two-week treatment, the uppermost fully expanded leaves that had been used for gas exchange and chlorophyll fluorescence analyses were destructively sampled. Their fresh weight (FW) was recorded and then digital images were taken using a Sony DSC-T99 14 megapixel camera (Sony, Tokyo, Japan). The leaves were sealed inside falcon tubes with their petiole submerged below deionized water and kept in darkness for $24 \mathrm{~h}$. Excess water on the surface of the leaves was removed using paper towels and their turgid weight (TW) recorded. The leaves were then dried for at least $72 \mathrm{~h}$ at $80^{\circ} \mathrm{C}$, when their weight remained constant this was considered to represent their dry weight (DW). The relative water content (RWC) of the leaves was determined as:

$$
\mathrm{RWC}=\left(\frac{\mathrm{FW}-\mathrm{DW}}{\mathrm{TW}-\mathrm{DW}}\right) \times 100
$$

Leaf area was determined from the digital images of the fresh leaves using the software program ImageJ (National Institutes of Health, Bethesda, MD, USA). The leaf mass per area (LMA) of the leaves was taken as their dry mass per unit fresh area.

\subsection{Statistical Analyses}

Statistical analyses were performed using SPSS 20 (IBM, Armonk, NY, USA). To test the effect of drought, salinity or salinity-drought on the normally distributed physiological and morphological parameters of quinoa we used a one-way ANOVA with an LSD post hoc test. Linear regression was used to investigate possible relationships between $P_{\mathrm{N}}$ to conductance to $\mathrm{CO}_{2}$. The Shapiro-Wilk test was applied to the ChlF data to assess the normality, and the Levene test was used to investigate homogeneity of variance. ChlF data was not normally distributed and the variance was not homogenous, and therefore the non-parametric Wilcoxon Signed-Rank Test was applied to the ChlF data to assess the mean rank differences of means between the control and groups subject to drought and/or salinity.

\section{Conclusions}

The results of this study have demonstrated that quinoa is a relatively drought-tolerant crop species exhibiting diffusive limitations to $P_{\mathrm{N}}$ under water deficit. The retention of photosynthetic capacity and PSII performance under drought indicate highly effective protective mechanisms to dissipate excess energy and neutralize oxidative stress. Stomatal and mesophyll limitations to the transport of $\mathrm{CO}_{2}$ played a major role in the response of quinoa to drought and salt stress. Modification of the physical and biochemical properties of the mesophyll layer may further enhance the photosynthetic performance of quinoa under drought stress (e.g., [72]). Salt stress induced short-term diffusive but also longer-term metabolic limitations to $\mathrm{CO}_{2}$ assimilation in quinoa. The deleterious effect of salinity was apparent in impaired RubisCO carboxylase activity, RuBP regeneration and PSII performance. Analysis of the chlorophyll fluorescence transient suggests that electron transport was impaired throughout PSII in salt-stressed quinoa. Salt stress degraded and damaged the pigment-protein complexes of the thylakoid membrane, likely inducing oxidative stress. While quinoa performed well under drought stress conditions, retaining photosynthetic capacity, it showed strong negative effects of salinity. This may suggest that quinoa would be suitable for cultivation in 
drought-prone Mediterranean areas not subject to strong salt stress (e.g., where irrigation is performed using sea-water: [73]). Selection of quinoa genotypes on the basis of gas exchange responses to salinity may be effective in identifying varieties capable of retaining photosynthetic function in growth conditions characterized by drought and salinity.

Supplementary Materials: The following are available online at www.mdpi.com/2223-7747/6/4/49/s1, Table S1: Diffusive and metabolic constraints to photosynthesis in quinoa during drought and salt stress.

Acknowledgments: This work was funded by the EU FP7 project WATBIO (Development of improved perennial non-food biomass and bio-product crops for water stressed environments-No. 311929).

Author Contributions: D.K. conceived and designed the experiments. D.K. and M.H. performed the experiments, analyzed the data and wrote the paper.

Conflicts of Interest: The authors declare no conflict of interest.

\section{Abbreviations}

\begin{tabular}{|c|c|}
\hline$P_{\mathrm{N}}$ & photosynthesis \\
\hline$P_{\mathrm{PR}}$ & photorespiration \\
\hline$G_{\mathrm{S}}$ & stomatal conductance \\
\hline$G_{m}$ & mesophyll conductance \\
\hline$G_{\text {tot }}$ & total conductance to $\mathrm{CO}_{2}$ \\
\hline$C_{\mathrm{i}}$ & concentration of $\left[\mathrm{CO}_{2}\right]$ within the internal sub-stomatal air-space \\
\hline$C_{c}$ & concentration of $\left[\mathrm{CO}_{2}\right]$ within the chloroplast envelope \\
\hline RuBP & ribulose-1,5-bisphosphate \\
\hline RubisCO & ribulose-1,5-bisphosphate carboxylase/oxygenase \\
\hline$V_{\mathrm{Cmax}}$ & ribulose-1,5-bisphosphate; maximum carboxylation rate of RubisCO \\
\hline$J_{\max }$ & maximum rate of electron transport for regeneration of RuBP \\
\hline$\Gamma^{*}$ & $\mathrm{CO}_{2}$ compensation point to photorespiration \\
\hline$R_{\mathrm{d}}$ & respiration in the light \\
\hline RWC & relative water content \\
\hline LMA & leaf mass per area \\
\hline PSI & photosystem I \\
\hline PSII & photosystem II \\
\hline$J_{\mathrm{F}}$ & PSII electron transport rate \\
\hline$F_{\mathrm{o}}$ & minimum fluorescence yield in dark-adapted conditions \\
\hline$F_{\mathrm{v}} / F_{\mathrm{o}}$ & an indicator of the activity of the oxygen-evolving complex on the donor side of PSII \\
\hline$\varphi \mathrm{D}_{\mathrm{o}}$ & quantum yield of energy dissipation \\
\hline $\mathrm{ABS} / \mathrm{RC}$ & absorption of chlorophyll antennae per reaction centre \\
\hline $\mathrm{DI}_{\mathrm{o}} / \mathrm{RC}$ & flux of energy dissipated for each reaction centre \\
\hline$F_{\mathrm{m}}$ & maximum fluorescence yield in dark-adapted conditions \\
\hline ФPSII & actual fluorescence yield in light-adapted steady-state conditions \\
\hline$\Delta \mathrm{V}_{\mathrm{IP}}$ & efficiency of the electron chain flux in the I to P phase of the chlorophyll a fluorescence \\
\hline$\delta \mathrm{R}_{\mathrm{O}}$ & efficiency of electron carriers in reducing end electron acceptors at the PSI acceptor \\
\hline$F_{\mathrm{v}} / F_{\mathrm{m}}$ & maximum quantum yield of PSII photochemistry \\
\hline$\varphi \mathrm{E}_{\mathrm{O}}$ & initial quantum yield of electron transport \\
\hline $\mathrm{ET}_{\mathrm{o}} / \mathrm{RC}$ & electron flux beyond plastoquinone A per reaction centre \\
\hline $\mathrm{PI}_{\mathrm{ABS}}$ & $\begin{array}{l}\text { a performance index based on the photochemical and non-photochemical energy } \\
\text { absorption of chlorophyll antennae }\end{array}$ \\
\hline $\mathrm{PI}_{\mathrm{TOT}}$ & performance index incorporating the concentration of reaction centres \\
\hline$F_{\mathrm{m}}^{\prime}$ & maximal fluorescence under light-adapted conditions \\
\hline$F_{\mathrm{S}}$ & steady-state fluorescence under light-adapted conditions \\
\hline$\Psi E_{\mathrm{O}}$ & $\begin{array}{l}\text { probability that harvested excitation energy is utilized for electron transport to the primary } \\
\text { plastoquinone A acceptor of PSII }\end{array}$ \\
\hline $\mathrm{TR}_{\mathrm{o}} / \mathrm{RC}$ & flux of trapped energy per reaction centre leading to the reduction of plastoquinone A \\
\hline $\mathrm{RC} / \mathrm{CS}_{\mathrm{O}}$ & density of PSII plastoquinone A reducing reaction centres \\
\hline
\end{tabular}




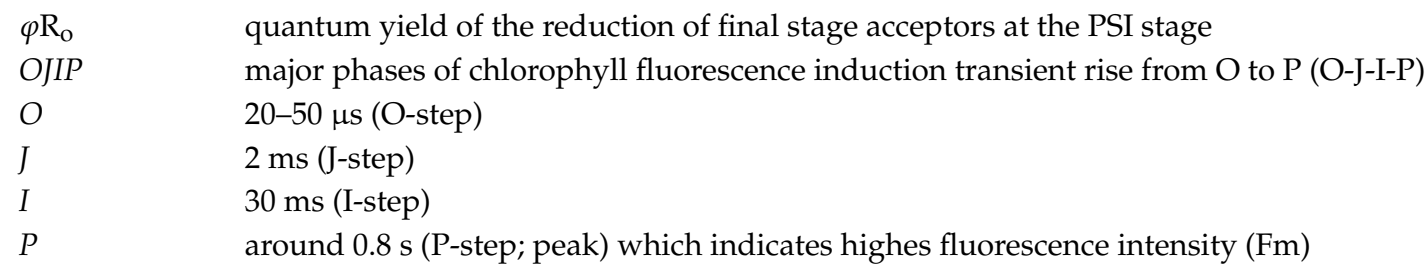

\section{References}

1. Fischer, G.; Hizsnyik, E.; Prieler, S.; Velthuizen, H.; Wiberg, D. Scarcity and Abundance of Land Resources: Competing Uses and the Shrinking Land Resource Base; Food and Agriculture Organisation of the United Nation: Rome, Italy, 2012.

2. Chaves, M.; Flexas, J.; Pinheiro, C. Photosynthesis under drought and salt stress: Regulation mechanisms from whole plant to cell. Ann. Bot. 2009, 103, 551-560. [CrossRef] [PubMed]

3. Flexas, J. Genetic improvement of leaf photosynthesis and intrinsic water use efficiency in $\mathrm{C}_{3}$ plants: Why so much little success? Plant Sci. 2016, 25, 155-161. [CrossRef] [PubMed]

4. Turral, H.; Burke, J.J.; Faurès, J.-M. Climate Change, Water and Food Security; FAO Water Reports; Food and Agriculture Organization of the United Nations: Rome, Italy, 2011; Volume 36.

5. Jacobsen, S.-E. The worldwide potential for quinoa (Chenopodium quinoa Willd.). Food Rev Int. 2003, 19, 167-177. [CrossRef]

6. Becker, V.I.; Goessling, J.W.; Duarte, B.; Cacador, I.; Liu, F.L.; Rosenqvist, E. Combined effects of soil salinity and high temperature on photosynthesis and growth of quinoa plants (Chenopodium quinoa). Funct. Plant Biol. 2017, 44, 665-678. [CrossRef]

7. Lavini, A.; Pulvento, C.; d'Andria, R.; Riccardi, M.; Choukr-Allah, R.; Belhabib, O. Quinoa's potential in the Mediterranean region. J. Agron. Crop Sci. 2014, 200, 344-360. [CrossRef]

8. Flexas, J.; Bota, J.; Escalona, J.M.; Sampol, B.; Medrano, H. Effects of drought on photosynthesis in grapevines under field conditions: An evaluation of stomatal and mesophyll limitations. Funct. Plant Biol. 2002, 29, 461-471. [CrossRef]

9. Demmig-Adams, B.; Adams, W.W. Photosynthesis: Harvesting sunlight safely. Nature 2000, 303, 371-374. [CrossRef] [PubMed]

10. Kalaji, H.M.; Jajoo, A.; Oukarroum, A.; Brestic, M.; Zivcak, M.; Samborska, I.A. Chlorophyll $a$ fluorescence as a tool to monitor physiological status of plants under abiotic stress conditions. Acta Physiol. Plant. 2016, 38, 1-11. [CrossRef]

11. Genty, B.; Briantais, J.-M.; Baker, N.R. The relationship between the quantum yield of photosynthetic electron transport and quenching of chlorophyll fluorescence. Biochim. Biophys. Acta (BBA) Gen. Subj. 1989, 990, 87-92. [CrossRef]

12. Flexas, J.; Bota, J.; Loreto, F.; Cornic, G.; Sharkey, T. Diffusive and metabolic limitations to photosynthesis under drought and salinity in C3 plants. Plant Biol. 2004, 6, 269-279. [CrossRef] [PubMed]

13. Zhou, J.; Wang, X.; Jiao, Y.; Qin, Y.; Liu, X.; He, K. Global genome expression analysis of rice in response to drought and high-salinity stresses in shoot, flag leaf, and panicle. Plant Mol. Biol. 2007, 63, 591-608. [CrossRef] [PubMed]

14. Razzaghi, F.; Ahmadi, S.H.; Adolf, V.I.; Jensen, C.R.; Jacobsen, S.E.; Andersen, M.N. Water Relations and Transpiration of Quinoa (Chenopodium quinoa Willd.) Under Salinity and Soil Drying. J. Agron. Crop Sci. 2011, 197, 348-360. [CrossRef]

15. Razzaghi, F.; Jacobsen, S.E.; Jensen, C.R.; Andersen, M.N. Ionic and photosynthetic homeostasis in quinoa challenged by salinity and Drought-Mechanisms of tolerance. Funct Plant Biol. 2015, 42, 136-148. [CrossRef]

16. Sanchez, H.B.; Lemeur, R.; Damme, P.V.; Jacobsen, S.-E. Ecophysiological analysis of drought and salinity stress of quinoa (Chenopodium quinoa Willd.). Food Rev Int. 2003, 19, 111-119. [CrossRef]

17. Jensen, C.R.; Jacobsen, S.E.; Andersen, M.N.; Nunez, N.; Andersen, S.D.; Rasmussen, L. Leaf gas exchange and water relation characteristics of field quinoa (Chenopodium quinoa Willd.) during soil drying. Eur. J. Agron. 2000, 13, 11-25. [CrossRef]

18. Sun, Y.; Liu, F.; Bendevis, M.; Shabala, S.; Jacobsen, S.E. Sensitivity of two quinoa (Chenopodium quinoa Willd.) varieties to progressive drought stress. J. Agron. Crop Sci. 2014, 200, 12-23. [CrossRef] 
19. Fghire, R.; Ali, O.I.; Anaya, F.; Benlhabib, O.; Jacobsen, S.-E.; Wahbi, S. Protective antioxidant enzyme activities are affected by drought in quinoa (Chenopodium quinoa Willd). J. Biol. Agric. Healthc. 2013, 3, $62-68$.

20. Munns, R. Comparative physiology of salt and water stress. Plant Cell Environ. 2002, 25, 239-250. [CrossRef] [PubMed]

21. Munns, R.; James, R.A.; Läuchli, A. Approaches to increasing the salt tolerance of wheat and other cereals. J. Exp. Bot. 2006, 57, 1025-1043. [CrossRef] [PubMed]

22. Talebnejad, R.; Sepaskhah, A.R. Physiological characteristics, gas exchange, and plant ion relations of quinoa to different saline groundwater depths and water salinity. Arch. Agron. Soil Sci. 2016, 62, 1347-1367. [CrossRef]

23. Ouerghi, Z.; Cornic, G.; Roudani, M.; Ayadi, A.; Brulfert, J. Effect of $\mathrm{NaCl}$ on photosynthesis of two wheat species (Triticum durum and T. aestivum) differing in their sensitivity to salt stress. J. Plant Physiol. 2000, 156, 335-340. [CrossRef]

24. Dionisio-Sese, M.L.; Tobita, S. Effects of salinity on sodium content and photosynthetic responses of rice seedlings differing in salt tolerance. J Plant Physiol. 2000, 157, 54-58. [CrossRef]

25. Shabala, S.; Hariadi, Y.; Jacobsen, S.-E. Genotypic difference in salinity tolerance in quinoa is determined by differential control of xylem $\mathrm{Na}^{+}$loading and stomatal density. J. Plant Physiol. 2013, 170, 906-914. [CrossRef] [PubMed]

26. Hariadi, Y.; Marandon, K.; Tian, Y.; Jacobsen, S.-E.; Shabala, S. Ionic and osmotic relations in quinoa (Chenopodium quinoa Willd.) plants grown at various salinity levels. J. Exp. Bot. 2010, 62, 185-193. [CrossRef] [PubMed]

27. Morales, A.J.; Bajgain, P.; Garver, Z.; Maughan, P.J.; Udall, J.A. Physiological responses of Chenopodium quinoa to salt stress. Int. J. Plant Physiol. Biochem. 2011, 3, 219-232.

28. Cocozza, C.; Pulvento, C.; Lavini, A.; Riccardi, M.; d'Andria, R.; Tognetti, R. Effects of increasing salinity stress and decreasing water availability on ecophysiological traits of quinoa (Chenopodium quinoa Willd.) grown in a Mediterranean-type agroecosystem. J. Agron. Crop Sci. 2013, 199, 229-240. [CrossRef]

29. Jacobsen, S.-E.; Mujica, A.; Jensen, C. The resistance of quinoa (Chenopodium quinoa Willd.) to adverse abiotic factors. Food Rev. Int. 2003, 19, 99-109. [CrossRef]

30. Lauteri, M.; Haworth, M.; Serraj, R.; Monteverdi, M.C.; Centritto, M. Photosynthetic diffusional constraints affect yield in drought stressed rice cultivars during flowering. PLoS ONE 2014, 9, e109054. [CrossRef] [PubMed]

31. Ethier, G.J.; Livingston, N.J. On the need to incorporate sensitivity to $\mathrm{CO}_{2}$ transfer conductance into the Farquhar-von Caemmerer-Berry leaf photosynthesis model. Plant Cell Environ. 2004, 27, 137-153. [CrossRef]

32. Harley, P.C.; Loreto, F.; Dimarco, G.; Sharkey, T.D. Theoretical considerations when estimating the mesophyll conductance to $\mathrm{CO}_{2}$ flux by analysis of the response of photosynthesis to $\mathrm{CO}_{2}$. Plant Physiol. 1992, 98, 1429-1436. [CrossRef] [PubMed]

33. De Herralde, F.; Biel, C.; Savé, R.; Morales, M.A.; Torrecillas, A.; Alarcón, J.J. Effect of water and salt stresses on the growth, gas exchange and water relations in Argyranthemum coronopifolium plants. Plant Sci. 1998, 139, 9-17. [CrossRef]

34. Tezara, W.; MartÍNez, D.; Rengifo, E.; Herrera, A.N.A. Photosynthetic responses of the tropical spiny shrub Lycium nodosum (Solanaceae) to drought, soil salinity and saline spray. Ann. Bot. 2003, 92, 757-765. [CrossRef] [PubMed]

35. Killi, D.; Bussotti, F.; Raschi, A.; Haworth, M. Adaptation to high temperature mitigates the impact of water deficit during combined heat and drought stress in $\mathrm{C}_{3}$ sunflower and $\mathrm{C}_{4}$ maize varieties with contrasting drought tolerance. Physiol. Plant 2017, 59, 130-147. [CrossRef] [PubMed]

36. Sorrentino, G.; Haworth, M.; Wahbi, S.; Mahmood, T.; Zuomin, S.; Centritto, M. Abscisic acid induces rapid reductions in mesophyll conductance to carbon dioxide. PLos ONE 2016, 11, e0148554. [CrossRef] [PubMed]

37. Jacobsen, S.-E.; Liu, F.; Jensen, C.R. Does root-sourced ABA play a role for regulation of stomata under drought in quinoa (Chenopodium quinoa Willd.). Sci. Hortic. 2009, 122, 281-287. [CrossRef]

38. Sade, N.; Gebremedhin, A.; Moshelion, M. Risk-taking plants: Anisohydric behavior as a stress-resistance trait. Plant Signal. Behav. 2012, 7, 767-770. [CrossRef] [PubMed]

39. Centritto, M.; Loreto, F.; Chartzoulakis, K. The use of low $\left[\mathrm{CO}_{2}\right]$ to estimate diffusional and non-diffusional limitations of photosynthetic capacity of salt-stressed olive saplings. Plant Cell Environ. 2003, 26, 585-594. [CrossRef] 
40. Reddy, A.R.; Chaitanya, K.V.; Vivekanandan, M. Drought-induced responses of photosynthesis and antioxidant metabolism in higher plants. J. Plant Physiol. 2004, 161, 1189-1202. [CrossRef]

41. Bongi, G.; Loreto, F. Gas-exchange properties of salt-stressed olive (Olea europea L.) leaves. Plant Physiol. 1989, 90, 1408-1416. [CrossRef] [PubMed]

42. Hanba, Y.; Miyazawa, S.; Terashima, I. The influence of leaf thickness on the $\mathrm{CO}_{2}$ transfer conductance and leaf stable carbon isotope ratio for some evergreen tree species in Japanese warm-temperate forests. Funct. Ecol. 1999, 13, 632-639. [CrossRef]

43. Flexas, J.; Diaz-Espejo, A.; Galmés, J.; Kaldenhoff, R.; Medrano, H.; Ribas-Carbo, M. Rapid variations of mesophyll conductance in response to changes in $\mathrm{CO}_{2}$ concentration around leaves. Plant Cell Environ. 2007, 30, 1284-1298. [CrossRef] [PubMed]

44. Solomon, A.; Beer, S.; Waisel, Y.; Jones, G.P.; Paleg, L.G. Effects of $\mathrm{NaCl}$ on the carboxylating activity of Rubisco from Tamarix jordanis in the presence and absence of proline-related compatible solutes. Physiol. Plant. 1994, 90, 198-204. [CrossRef]

45. Seemann, J.R.; Critchley, C. Effects of salt stress on the growth, ion content, stomatal behaviour and photosynthetic capacity of a salt-sensitive species, Phaseolus vulgaris L. Planta 1985, 164, 151-162. [CrossRef] [PubMed]

46. Wang, Y.; Nii, N. Changes in chlorophyll, ribulose bisphosphate carboxylase-oxygenase, glycine betaine content, photosynthesis and transpiration in Amaranthus tricolor leaves during salt stress. J. Hortic. Sci. Biotechnol. 2000, 75, 623-627. [CrossRef]

47. Seki, M.; Narusaka, M.; Ishida, J.; Nanjo, T.; Fujita, M.; Oono, Y. Monitoring the expression profiles of 7000 Arabidopsis genes under drought, cold and high-salinity stresses using a full-length cDNA microarray. Plant J. 2002, 31, 279-292. [CrossRef] [PubMed]

48. Sobhanian, H.; Razavizadeh, R.; Nanjo, Y.; Ehsanpour, A.A.; Jazii, F.R.; Motamed, N. Proteome analysis of soybean leaves, hypocotyls and roots under salt stress. Proteome Sci. 2010, 8, 19. [CrossRef] [PubMed]

49. Slabu, C.; Zörb, C.; Steffens, D.; Schubert, S. Is salt stress of faba bean (Vicia faba) caused by $\mathrm{Na}^{+} \mathrm{or}^{-}$ toxicity? J. Plant Nutr. Soil Sci. 2009, 172, 644-651. [CrossRef]

50. Bañuls, J.; Primo-Millo, E. Effects of chloride and sodium on gas exchange parameters and water relations of Citrus plants. Physiol Plant. 1992, 86, 115-123. [CrossRef]

51. Luo, Q.; Yu, B.; Liu, Y. Differential sensitivity to chloride and sodium ions in seedlings of Glycine max and G. soja under $\mathrm{NaCl}$ stress. J. Plant Physiol. 2005, 162, 1003-1012. [CrossRef] [PubMed]

52. Olesen, K.; Andréasson, L.-E. The function of the chloride ion in photosynthetic oxygen evolution. Biochemistry 2003, 42, 2025-2035. [CrossRef] [PubMed]

53. Kawakami, K.; Umena, Y.; Kamiya, N.; Shen, J.-R. Location of chloride and its possible functions in oxygen-evolving photosystem II revealed by X-ray crystallography. Proc. Natl. Acad. Sci. USA 2009, 106, 8567-8572. [CrossRef] [PubMed]

54. Schreiber, U.; Bilger, W.; Neubauer, C. Chlorophyll fluorescence as a nonintrusive indicator for rapid assessment of in vivo photosynthesis. In Ecophysiology of Photosynthesis; Schulze, E.-D., Caldwell, M.M., Eds.; Springer: Berlin/Heidelberg, Germany, 1995; pp. 49-70.

55. Strasser, R.J.; Tsimilli-Michael, M.; Srivastava, A. Analysis of the chlorophyll a fluorescence transient. In Chlorophyll a Fluorescence; Papageorgiou, G., Govindjee, F.C., Gantt, E., Golbeck, J., Golden, S., Eds.; Springer: Dordrecht, The Netherlands, 2004; pp. 321-362.

56. Belgio, E.; Johnson Matthew, P.; Jurić, S.; Ruban Alexander, V. Higher plant photosystem II light-harvesting antenna, not the reaction center, determines the excited-state lifetime-Both the maximum and the nonphotochemically quenched. Biophys. J. 2012, 102, 2761-2771. [CrossRef] [PubMed]

57. Tavakkoli, E.; Rengasamy, P.; McDonald, G.K. High concentrations of $\mathrm{Na}^{+}$and $\mathrm{Cl}^{-}$ions in soil solution have simultaneous detrimental effects on growth of faba bean under salinity stress. J. Exp. Bot. 2010, 61, 4449-4459. [CrossRef] [PubMed]

58. Schansker, G.; Tóth, S.Z.; Strasser, R.J. Methylviologen and dibromothymoquinone treatments of pea leaves reveal the role of photosystem I in the Chl a fluorescence rise OJIP. Biochim. Biophys. Acta (BBA) Bioenergy 2005, 1706, 250-261. [CrossRef] [PubMed]

59. Ceppi, M.G.; Oukarroum, A.; Çiçek, N.; Strasser, R.J.; Schansker, G. The IP amplitude of the fluorescence rise OJIP is sensitive to changes in the photosystem I content of leaves: A study on plants exposed to magnesium and sulfate deficiencies, drought stress and salt stress. Physiol. Plant. 2012, 144, 277-288. [CrossRef] [PubMed] 
60. Pospíšil, P. Production of reactive oxygen species by photosystem II. Biochim. Biophys. Acta (BBA) Bioenergy 2009, 1787, 1151-1160. [CrossRef] [PubMed]

61. Klute, A. Methods of soil analysis. Part 1. In Physical and Mineralogical Methods; American Society of Agronomy, Inc.: Madison, WI, USA, 1986.

62. Panuccio, M.R.; Jacobsen, S.E.; Akhtar, S.S.; Muscolo, A. Effect of saline water on seed germination and early seedling growth of the halophyte quinoa. AoB Plants 2014, 6. [CrossRef] [PubMed]

63. Loriaux, S.; Avenson, T.; Welles, J.; McDermitt, D.; Eckles, R.; Riensche, B. Closing in on maximum yield of chlorophyll fluorescence using a single multiphase flash of sub-saturating intensity. Plant Cell Environ. 2013, 36, 1755-1770. [CrossRef] [PubMed]

64. Galmes, J.; Flexas, J.; Keys, A.J.; Cifre, J.; Mitchell, R.A.C.; Madgwick, P.J. Rubisco specificity factor tends to be larger in plant species from drier habitats and in species with persistent leaves. Plant Cell Environ. 2005, 28, 571-579. [CrossRef]

65. Kok, B. A critical consideration of the quantum yield of Chlorella photosynthesis. Enzymologia 1948, 13, 1-56.

66. Kirschbaum, M.U.; Farquhar, G.D. Investigation of the $\mathrm{CO}_{2}$ dependence of quantum yield and respiration in Eucalyptus pauciflora. Plant Physiol. 1987, 83, 1032-1036. [CrossRef] [PubMed]

67. Laisk, A.; Loreto, F. Determining photosynthetic parameters from leaf $\mathrm{CO}_{2}$ exchange and chlorophyll fluorescence-Ribulose-1,5-bisphosphate carboxylase oxygenase specificity factor, dark respiration in the light, excitation distribution between photosystems, alternative electron transport rate, and mesophyll diffusion resistance. Plant Physiol. 1996, 110, 903-912. [PubMed]

68. Von Caemmerer, S. Biochemical Models of Leaf Photosynthesis; Csiro Publishing: Collingwood, Australia, 2000; p. 152.

69. Sharkey, T.D. Estimating the rate of photorespiration in leaves. Physiol. Plant. 1988, 73, 147-152. [CrossRef]

70. Bunce, J.A. Light dependence of carboxylation capacity for C-3 photosynthesis models. Photosynthetica 2016, 54, 484-490. [CrossRef]

71. Flexas, J.; Díaz-Espejo, A.; Berry, J.; Cifre, J.; Galmés, J.; Kaldenhoff, R. Analysis of leakage in IRGA's leaf chambers of open gas exchange systems: Quantification and its effects in photosynthesis parameterization. J. Exp. Bot. 2007, 58, 1533-1543. [CrossRef] [PubMed]

72. Adachi, S.; Nakae, T.; Uchida, M.; Soda, K.; Takai, T.; Oi, T. The mesophyll anatomy enhancing $\mathrm{CO}_{2}$ diffusion is a key trait for improving rice photosynthesis. J. Exp. Bot. 2013, 64, 1061-1072. [CrossRef] [PubMed]

73. Loreto, F.; Centritto, M.; Chartzoulakis, K. Photosynthetic limitations in olive cultivars with different sensitivity to salt stress. Plant Cell Environ. 2003, 26, 595-601. [CrossRef] 